\title{
MACROFUNGI FROM SIDDABABA SACRED GROVE: WEST, NEPAL
}

\author{
Hari P. Aryal ${ }^{1}$, Rajendra Poudel ${ }^{2}$ and U. Budathoki ${ }^{2}$
}

\begin{abstract}
During the survey of wild edible mushrooms in between tropical and temperate belt of Nepal in rainy season 2010 -2012, many macro fungal species were collected and identified. The paper highlights on new record of Volvorella taylorii (Berk and Broome) Sing. The species was reported and re-described for the first time from Nepal. Along with, taxonomic description of the two species of Volvorella found in the same studied area, have also been provided. Phytogeographycally, the sample collected area lies within a narrow limit of 9.75 hectare at the altitude between 335 and 400 masl in tropical deciduous riverine forest. The dried specimens are housed in the Tribhuvan University Central Herbarium (TUCH), Kirtipur Kathmandu, Nepal.
\end{abstract}

Kew words: Basidiomycetes, Taxonomy, Volvorella taylorii

\section{INTRODUCTION}

Macro-fungal studies have long been of interest to scientists in the world for their significant roles in forest ecosystem and human life. Macrofungi are used in the pharmaceutical industry, the mass production of cultivated fungi is used in the food industry, and they play vital role in biodegradation (De Boer et al. 2005).

Fruiting body of edible species of macro-fungi are mushrooms. Nepal is considered as the homeland for the mushroom floral diversity (Aryal and Budhathoki, 2012a). So far, 816 mushroom species have been identified (Adhikari, 2009; Aryal and Budhathoki, 2013abc and Aryal et al. 2014), which include 228 edible (Christensen et al. 2008), 66 poisonous (Pandey, 2008 and Adhikari, 2009) and 75 medicinal species (Adhikari, 2009; Aryal and Budhathoki, 2013; Aryal et al. 2014). The investigation and study on mushrooms of Nepal started since $19^{\text {th }}$ century (Llyod, 1808). Since then several papers have been published and several botanical investigations have been done. Among these, very few reveal the studies and investigation on wild mushrooms from western Nepal. The area has not been previously investigated so far. The present works explore on the systematics of Volvorella bombaycina (Schaeff. ex Fr.) Sing and Volvorella volvacea (Fr.) Sing, with the addition of new species Volvorella taylorii (Berk and Broome) Sing. Presently three taxa of the genus Volvorella have been reported from Siddababa religious forest, a region of tropical climate and west-south region of Nepal. Among the three, one taxon is new to Nepal, and has not been reported previously.

\footnotetext{
1 Paklihawa Campus, Bhairahawa, Institute of Agriculture and Animal Science, Tribhuvan University, Nepal E-mail: hahariprasadaryal06@gmail.com

${ }^{2}$ Central Department of Botany, Tribhuvan University, Kirtipur, Kathmandu, Nepal
} 


\section{STUDY AREA}

The study area lies in Lumbini zone, Palpa district, Dovan VDC, WN-7, Siddababa temple territoty in the west Nepal and towards the north of Butwal Municipality (Figure 1). Phytogeographically, it embraces tropical riverine belt along with loamy sand to sandy loam soil. The forest vegetation is dominated by members of the Dipterocarpaceae, Combretaceae, Leguminosae and Myrtaceae families. This study area included 9.75 hectare of forest (DFO, 2007) and lies between $27.73399^{\circ} \mathrm{N}$ $27.734000^{\circ} \mathrm{N}$ latitude and $83.41398^{\circ} \mathrm{E}-83.41400^{\circ} \mathrm{E}$ longitudes. The altitudinal range varies between 335 and 400 masl. The average annual rainfall is $1391 \mathrm{~mm}$ (GoN, 2010).

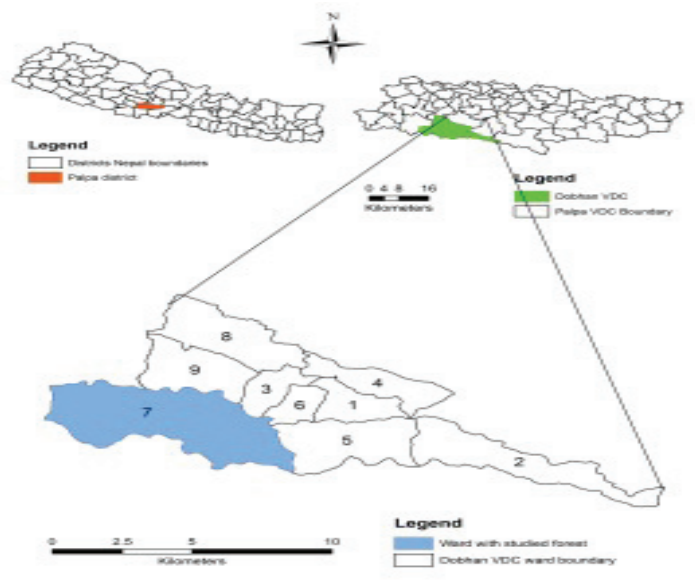

Figure 1. Map of Sample collection site

\section{METHODOLOGY}

Survey was conducted from first week of May in 2010 and specimens were collected from first week of June 2010 to laxt week of October, 2012. Mushroom samples were photographed in their natural habitat and their morphological characters were noted. Spore print was taken. The samples were well dried and packed in wax paper bags. They were wrapped with aluminums foil bags to prevent from the external infection. As well as prevent from the intermixing of the spores, proper tag numbers were used. The habitat including ecological parameters viz. altitude (by altimeter), vegetation composition, soil type, soil pH (by digital pH meter), soil moisture (by nail pH meter), humidity, temperatures and time (by means of Thermo-Hygrometer) were recorded. The paper bags were brought to central Department of Botany, Tribhuvan University, for further microscopic examination.

Some of the collected specimens were preserved in a liquid preservative (25:5:70 $\mathrm{ml}$ rectified alcohol + formalin + distilled water), (Hawksworth et. al. 1995) and 
rest are in dry preservation (Atri and Saini, 2000). The specimens were studied based on the macroscopic, microscopic and habitat characteristics, slide was prepared and spores were measured with microphotograph of fruiting body from the prepared slide. For determining the groups, chemical reaction (Tulloss, 1994) was carried out using different solution of $5 \% \mathrm{KOH}, \mathrm{NH}_{3} \mathrm{OH}, \mathrm{FeSO}_{4}$ (crystal and solution) and its colour was compared with the commercial colour chart leaf let. (www.asianpaints.com). For microscopic study, the specimens were sectioned by using a sharp razor blade. The cyanophility was observed in cotton blue mounted in lactophenol reagent. The photographs were taken by Digital Sony DSC S980 Camera. Macroscopic and microscopic characters were studied under an Olympus microscope (Model No. CX 22), and latitude and longitude were taken by means of GPS compass (Garmin, Eterex, Germany).

The samples were identified with the help of relevant taxonomic literature (Shaffer, 1957 and 1962; Singer, 1986; Saccardo, 1887 and Seok et al. 2002) and Website (biodiversity library.org, Index fungorum, Jstor.org, Mycobank.org, Scirus.com and tropicos.org). Basically, the mushroom was identified on the basis of spore print (colour), size of spore, gills and its habitat. The voucher specimens are deposited in TUCH.

\section{RESULTS}

\section{KEY TO THE SPECIES}

\section{Identifing Characters of the Volverella}

It bears basidia in a well defined hymenium, which becomes exposed while basidiospores are still young and underdeveloped, the basidiocarp in order Pluteales (Agaricales) is fleshy, sub fleshy, leathery, membranaceous or fragile. Basidia are 2, 4 or 8 spored and one called at maturity. The spores are forcibly discharged from the sterigmata at maturity.

\section{Volvorella taylorii (Berk and Broome) Sing.}

Monoson, H.L., A.S. Methven and W.J. Sundberg. 1993. Illinois species of volvariella (Basidiomycetes, Agaricales, Pluteaceae). Mycotaxon 49: 269-278. Shaffer, R.L. 1957. Volvariella in North America. Mycologia 49(4): 545-549.Kuo, M. 2008. Volvariella taylotia. Retrieved from the Mushroom Expert.Com Web site: http://www.mushroomexpert.com/volvariella_taylori.html

\section{Local Name: Peeiroutee (Tharu).}

Taxonomic Position: Basidiomycotina, Basidiomycetes, Hymenomycetes, Agaricales (Pluteales), Pluteaceae, Volvariella (Figure 2.).

Taxonomic description :( Kuo, 2008)

Basidiocarp: Initially grayish white egg-like structure consisting of a basidiocarp covered with volva. On maturing, the basidiocarp consisting of pileus and stipe emerge out of the volva (Figure 2.1-2.2). Annulus and clamp connection are absent. Macro and micro morphological characters with systematic treatment of chemical reaction (Table 1,2 and 3 ).

Host: Saw dust. Edibility: Edible. Ecology: Sapbrobic, growing alone or gregariously on the ground; found in woods, often near brushpiles and woody debris, or in urban 
areas in grassy waste places. Habitat: Terrestrial, saprobic in nature (the specimens were collected from the rice straw debris on 12 August, 2011) found growing is this area from the month of June/July to October/November (according to local inhabitants). Season: May to October; with heat, all year.

Specimen examined: Nepal, Palpa district, (Siddababa Religious forest), 380m; long. 83.49875 ${ }^{\circ} \mathrm{E}$; lat. $27.57412^{\circ} \mathrm{N}$; Aspect: $220^{\circ} \mathrm{W}$; Slope: $40^{\circ} \mathrm{S} / \mathrm{W}$; Temp.: 20.3-31.9 C; Humidity: 72-87 \%; Soil pH: 7.6; Soil moisture: 6.5, Time: 17.02 pm; Voucher No. 1009428; date: 09.09.2012.Growing on compost piles (decomposed paddy straw), Palpa. No previous record from the country, hence new to Nepal.

Distribution: widely distributed in India and Nepal.

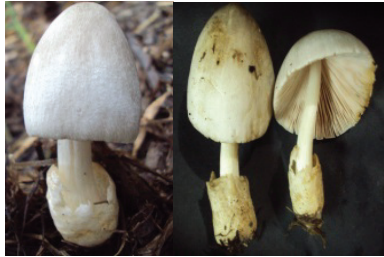

Figure 2.1 Figure 2.2

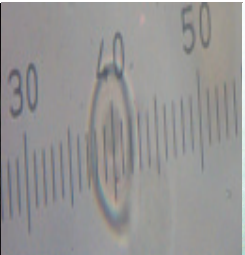

Figure 2.3

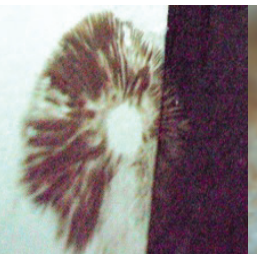

Figure 2.4

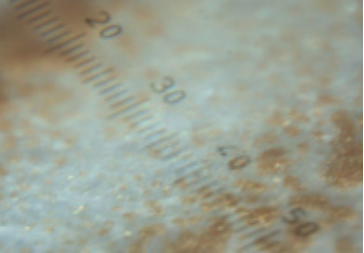

Figure 2.5

Figure 2. Volvorella taylorii. Figure 2.1 Basidiocarp, Figure 2.2 Dorsal and ventral view of basidiocarps, Figure 2.3 Spore $(1 \mathrm{div}=1.66 \mu \mathrm{m})$, Figure 2.4 Spore print, Figure 2.5 Distance between two lammelle $(1 \mathrm{div}=11.66 \mu \mathrm{m})$.

Volvorella bombaycina (Schaeff. ex Fr.) Sing.

Syn. Volvaria bombycina (Berk. Sec Barb), Phillips, Mushrooms and other Fungi of Great Britain and Europe. 112, (1981). - Orson and Millar, Mushrooms of North America, 170, (1984). - Purukayastha and Chandra, Manual of Indian Edible Mushrooms, 127, (1985). - Saccardo, Sylloge de fungorum vol. 5, 656, (1887). Konemann, The Encyclopedia of Mushrooms, 121, (1999), -Krieger, The Mushroom Handbook, 453, (1967).-Rea, British Basidiomycetaceae, 94, (1922).-Koneman. Mushrooms of Japan, 122, (1999).

Local Name: Kathchueenya (Tharu)

Taxonomic Position: Basidiomycotina, Basidiomycetes, Hymenomycetes, Agaricales (Pluteales), Pluteaceae, Volvariella (Figure 3.)

Taxonomic description:

Basidiocarp: White cap covered with silky fibrils, viscid, sac-like, dirty sported volva, growing on wood or ground (Table 1, 2 and 3). Annulus and clampconnection absent.

Host: living trees. Edibility: Edible. Ecology: Saprobic, growing alone or gregariously on the ground; found in woods, often near brushpiles and woody debris, or in urban areas in grassy waste places. Habitat: Usually solitary, on rotting broadleaf tree trunks, in holes in living trees, sometimes some yards above ground, and on hollow stumps. Season: May to October.

Specimen examined: Nepal, Palpa district (Siddababa Religious forest), 400m; long. 83.51675 E; lat. $27.61321^{\circ} \mathrm{N}$; Aspect: $220^{\circ} \mathrm{W}$; Slope: $40^{\circ} \mathrm{S} / \mathrm{W}$; Temp.: 20.3-31.9 ${ }^{\circ} \mathrm{C}$; Humidity: 72-87 \%; Soil pH: 7.6; Soil moisture: 6.8, Time: 17.02 pm; Voucher 
No. 1107979, Date: 15.09.2012. Growing on living tree (Shorea robusta). New to area of collection.

Previously reported: On groove of populus trees, Kirtipur from 1320m (Pandey, 2008).

Distribution: Europe, N. America, India and Nepal.

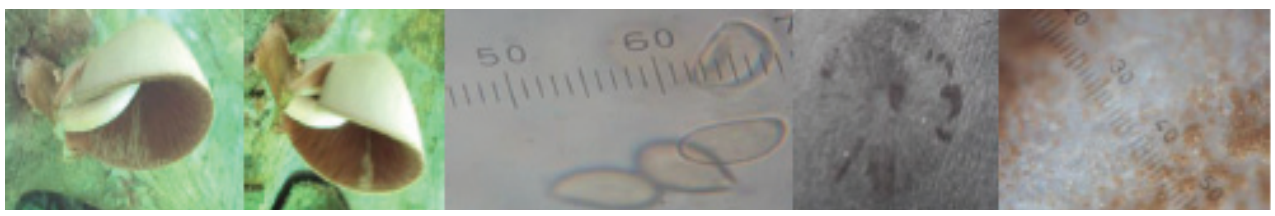

Figure 3.1

Figure 3.2 Figure 3.3

Figure 3.4

Figure 3.5

Figure 3. Volvorella bombaycina (Schaeff. ex Fr.) Sing.

Figure 3.1 and 3.2 Basidiocarp, Dorsal and ventral view, Figure $3.3(1 \mathrm{div}=1.66 \mu \mathrm{m})$, Figure 3.4 Spore print, Figure3.5 Distance between two lammelle (1div=11.66 $\mu \mathrm{m})$.

Volvorella volvacea (Fr.) Sing.

Syn. Volvorella volvacea (Bull. ex Fr.) Volvaria volvacea (Bull.) Sacc. Sing. Local name: poor chhtta (Tharu).

Common name: Paddy Straw mushroom, Chinese mushroom or Contonese mushroom.

Taxonomic Position: Basidiomycotina, Basidiomycetes, Hymenomycetes, Agaricales (Pluteales), Pluteaceae, Volvariella (Figure 4.).

Taxonomic description:

Basidiocarp: Sporophores usually growing solitary or gregarious on rotten paddy straw heaps; centrally stipitate (Table 1,2 and 3). Annulus and clampconnection absent. Host: Rice straw. Edibility: Edible. Ecology: Saprobic, growing alone or gregariously on rotten paddy straw heaps. Habitat: greenhouses or gardens, on sawdust or other vegetable residue, also in areas where field mushrooms are cultivated. Season: May to October; when the temperature remains optimum (22$30^{\circ} \mathrm{C}$ ), they are found throughout the year.

Specimen examined: Nepal, Palpa district (Siddababa Religious forest), 335m; long. $83.41400^{\circ} \mathrm{E}$; lat. $27.73400^{\circ} \mathrm{N}$; Aspect: $220^{\circ} \mathrm{W}$; Slope: $40^{\circ} \mathrm{S} / \mathrm{W}$; Rain fall: $15 \mathrm{~mm}$, Temp.: 20.3-31.9 ${ }^{\circ} \mathrm{C}$; Humidity: $72-87 \%$; Soil pH: 7.6; Soil moisture: 6.3, Time: 17.02 pm; Voucher No. 1109856, Date: 15.09.2012. Growing on compost piles New to area of collection.

Previously reported: On groove of populus trees, Kirtipur from 1320m,(Pandey, 2008).

Distribution: Europe, North America, India and Nepal

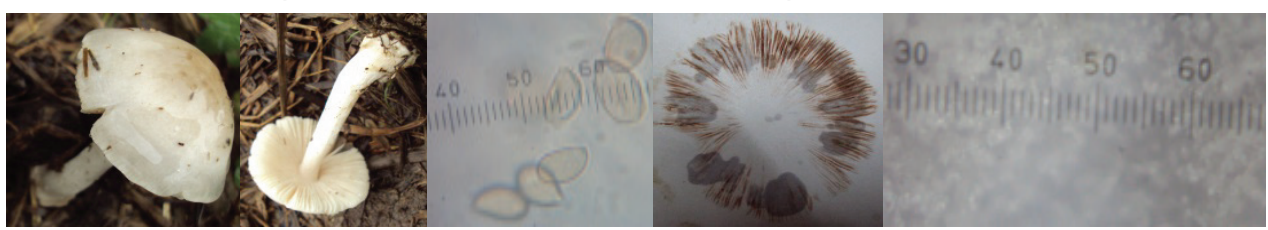

Figure 4.1

Figure 4.2.

Figure 4.3

Figure 4.4

Figure 4.5 
Figure 4. Volvorella volvacea Figure 4.1 and 4.2 Basidiocarp of dorsal and ventral view, Figure 4.3 Spore $(1 \mathrm{div}=1.66 \mu \mathrm{m})$, Figure 4.4 . Spore print, Figure 4.5 Distance between two lammelle (1div=11.66 $\mu \mathrm{m})$.

\section{DISCUSSIONS}

Volvorella is principally a tropical genus, and some species are also found in temperate region, frequently in forests, cultivated fields, gardens, straw heaps and greenhouse; a few grow on wood and one is parasitic on other mushrooms. These phytodiversity and ecological conditions provide a good homeland for the growth of tremendous amount of parasitic, saprophytic and mycorrhizal fungi in the region (Aryal et al., 2012b). All the members of the genus Volvaria play an important role in forest ecology due to saprophytic in nature which occurs in the Shorea-SchimaCastanopsis-Quercus-Rhododendron and Betula utilis forests ranging between 60 and $3000 \mathrm{~m}$ in Nepal. This saprophytic fungi and its prevailing environment has not been well studied.

Species of this genus are indigenous and are well appreciated in the study sites. It has high medicinal importance and high protein content (Shing and Shing, 2005). The increasing depletion of forest is an alarming signal in the appearance, distribution and dominance of these species. The present investigation shows that vascular flora favors the growth of numerous species of mushrooms. The litter debris of these floras favors the regulation and maintenance of temperature and moisture in the soil.

\section{CONCLUSION}

The recent investigation on macro-fungal studies of this area is the genus Volvariella created an enthusiasm towards its intensive exploration. This genus is widely spread throughout the country in tropical to temperate belt of Nepal. It needs extensive investigation to find out their morphological characters, species richness and distribution pattern and species diversity. It needs special attention to conserve against the threat to avoid their unmanaged and unscientific exploitation by the people. Therefore, methods of harvesting should be done by application of more scientific rather than traditional methods. The mycoelements prevailing in this area need sustainable conservation and utilization. Hence, Volvariella taylorii is a new record from Nepal.

\section{ACKNOWLEDGMENT}

The authors would like to acknowledge Nepal Academy of Science and Technology for providing research grant. Thanks are due to Central Department of Botany, Tribhuvan University for providing the laboratory facilities. The authors are also grateful to the Institute of Agriculture and Animal Science for granting study leave to one of them (Mr. Hari Prasad Aryal). The authors are also thankful to Dr. M.K. Adhikari for his kind cooperation on this work. Sincere thanks are extended to local people for providing information. 

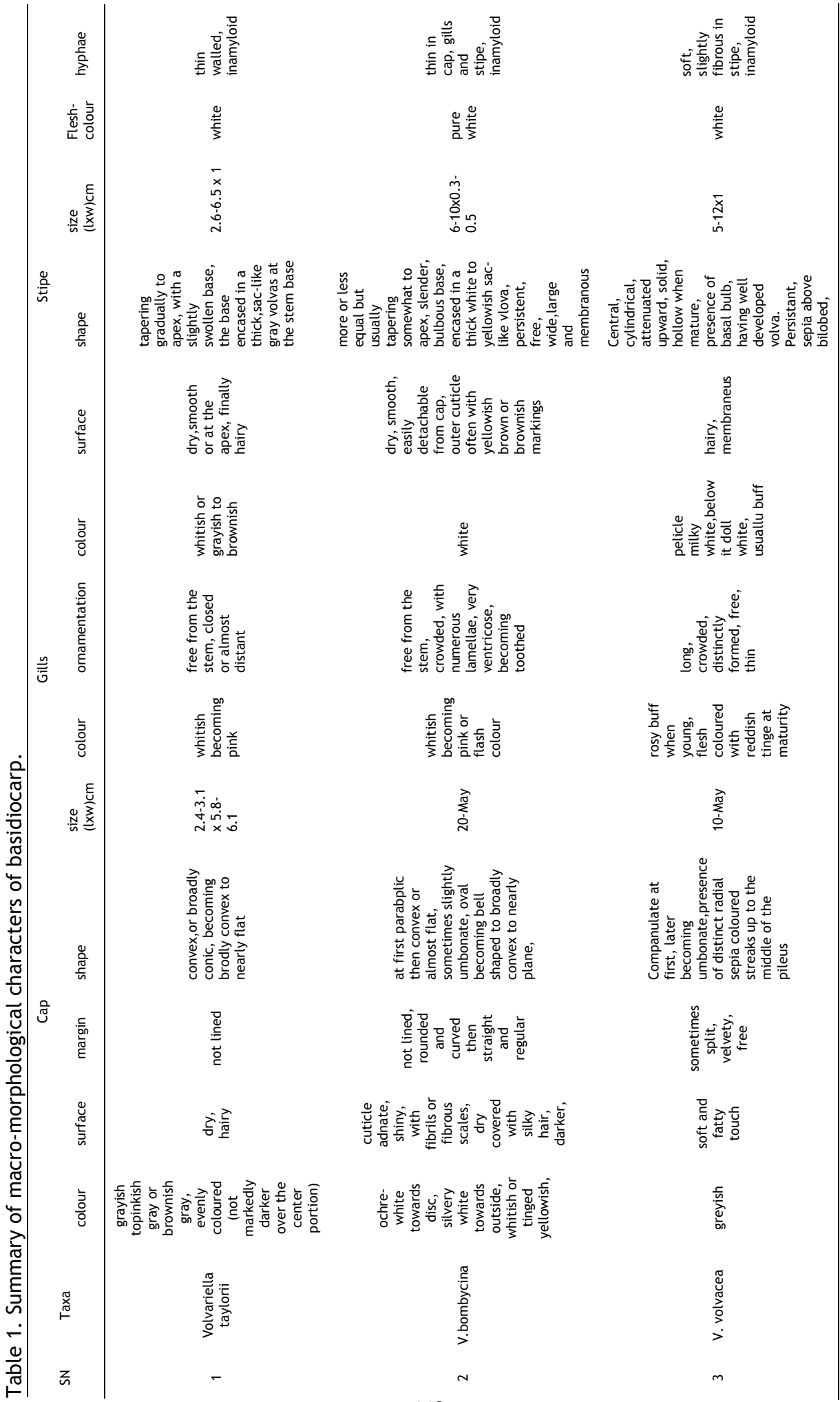


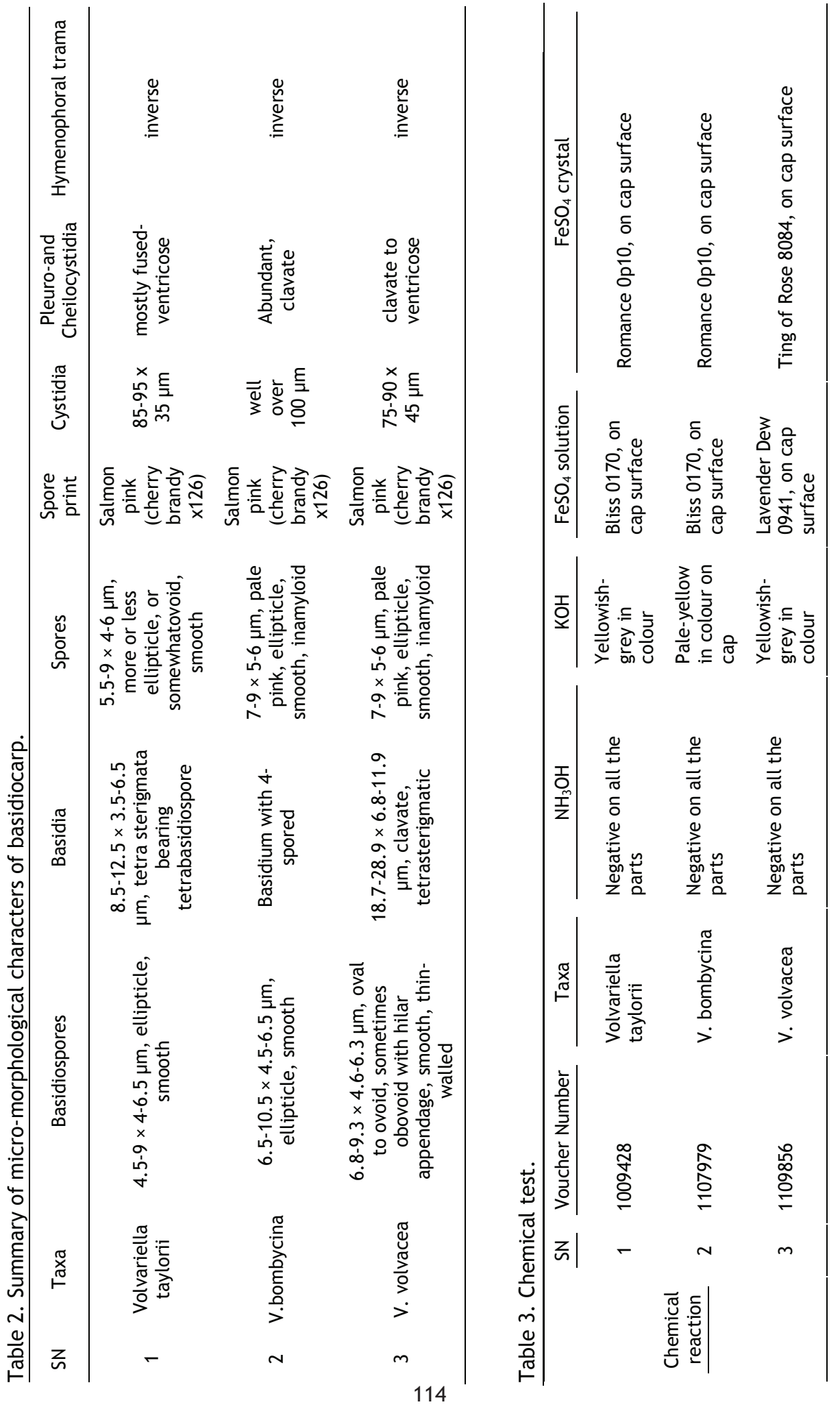




\section{REFERENCES}

Adhikari, M.K., 2009. Researches on the Nepalese mycoflora. Adhikari, K.S., Alka Basti Marga,Kathmandu, Nepal. pp. 82.

Aryal, H.P. and Budhathoki, U., 2012a. Macro-fungi of Karhiya Community Forest, western Terai, Nepal. Nepalese Jour. of Bioscience 2: 93-97.

Aryal, H.P. Budhathoki, U. and Adhikari, M.K., 2012b. Mycodiversity in Peepaldanda Community Forest, Western Terai Region of Nepal. Bull. Dept.Pl.Res.No.34. 13-17.

Aryal, H.P. and udhathoki, U., 2013a. Buchwaldoboletus lignicola (Basidiomycetes), an Inedible wild mushroom New to Nepal. Our Nature 11 (1): 31-35.

Aryal, H.P. and Budhathoki, U., 2013b. The Genus Amanita (Pers.) in Lumbini zone, Nepal. Scientific World 11 (11): 113-120.

Aryal, H.P. and U. Budhathoki. 2013c. Termitomyces albuminosus (Berk.) Heim a New Fungal Record from Arghakhnchi, Nepal. OAKS. 9: 44-47.December, 2013g. Nainital, India.

Aryal, H.P., U. Budhathoki and R.D. Tiwari. 2014. Termitomyces microcarpus (Berk. \& broome) R. Heim: A New records from Nepal. Jour. Mycol. Pl. Pathol. 2014. 44(1): 13-18

Berkeley, M.J., 1838. Description of exotic fungi in the collection of Sir W. J. Hooker from memories and notes of J. F. Klotsch with addition and correction. Ans. Natutal History 3: 375-401.

Christensen, M., Devkota, S. and Bhattarai, S., 2008. Use of wild edible mushrooms in the Annapurna conservation area, Nepal Jour. Mycol. Phytopath. Soc. Nep. 1:1-6.

De Boer, W. Folman, L.B. Summerbell, R.C. and Boddy, L., 2005. Living in a fungal world: Impact of fungi on soil bacterial niche development. FEMS Mycrobiol Review. 29: 795811.

DFO., 2007. District Forest Office: Brief Introduction and Progress Report.

GON. (Government of Nepal). 2010. Climatological and agro meteorological records of Nepal.Government of Nepal. Ministry of Environment, Science and Technology. Department of Hydrology and Meteorology, Kathmandu, Nepal.

Hawksworth, D.L. Kirt, P.M. Sutton, B.C. and Pegler, D.N., 1995. Ainsworth and Bisby's Dictionary of Fungi (8th ed.) International Mycological institute CAB International, Wallingford, Oxon, U.K.pp.616.

Kuo, M. 2008. Volvariella taylori. Retrieved from the Mushroom Expert. Com Web site: http://www.mushroomexpert.com/volvariella_taylori.html.

Llyod, C.G., 1808. Mycological notes. Mycology. Cincinnati, Ohio: Llyod Library \& Museum.

Monoson, H.L. Methven A.S.and Sundberg, W.J., 1993. Illinois species of Volvariella (Basidiomycetes, Agaricales, Pluteaceae). Mycotaxon 49: 269-278.

Pandey, N., 2008. Mushroom Diversity in central Nepal: An ethnomycological Approach. PhDdissertation submitted to the Central Department of Botany, Tribhuvan University, Nepal.

Phillips, R.,1981. Mushrooms and other Fungi of Great Britain and Europe. Pan Book Ltd. London.

Purukayastha, R.P. and Chandra, A., 1985. Manual of Indian edible mmushrooms. Jagendra Book Agency. New Delhi, India.

Saccardo, P.A., 1887. Sylloge de Fungorum.5. Pavia. pp.1146.

Saini, S.S and Atri, N.S., 2000. Collection and Study of Agarics- An Introduction. Indian Jour. of Mushroom. 18 (1\&2): 1-5.

Seok, S.J. Kim, Y.S. Weon, H.Y. Lee, K.H. Park, K.M. Min, K.H. and Yoo, K.H., 2002. Taxonomic study on Volvariella in Korea. Mycobiology 30: 183-192

Shaffer, R.L., 1957. Volvariella in North America. Mycologia 49: 545-579.

Shaffer, R.L., 1962. Synonyms, new combinations, and new species in Volvariella (Agaricales).ycologia 54: 563-572.

Shrestha, K. 1998. Dictionary of Nepalese Plant Names. Mandala Book Point, Kantipath,Kathmandu, Nepal. 267 p. 
Singer, R., 1951. Type studies on Basidiomycetes. Sydowia. 5: 445-475.

Singer, R., 1986. The agaricales in modern taxonomy (4th edition). Bishen Singh Mahendra Pal Singh, Dehradun, India.

Shingh, R. and U. C. Shingh. 2005. Modern Mushroom Cultivation. Shyam Printing Press, Jodhpur, India.

Stainton, J.D.A. 1972. Forest of Nepal. John Murray Ltd., London.

Tulloss, R.E., 1994. Seminario sobre Amanita (Supporting Materials for a Seminar on Amanita). (Univ. Autón. Tlaxcala). pp.127. 